27. Nataf, B. M., and Chaikoff, I. L.: Effect of hypophysectomy of the pregnant rat on ${ }^{131}$ I metabolism of the fetal thyroid gland. Endocrinology, 73: 518 (1963).

28. Robin, N. I., Selenkow, H. A., Fang, V. S., Refetoff, S., Paisecki, G Rauschecker, H., and Jackson, B. T.: Bidirectional thyroxine exchange in pregnant sheep. Hormones, 3: 235 (1972).

29. Stabenau, J. R., and Pollin, W.: Adult protein-bound iodine and maturity at birth in monozygotic twins. J. Clin. Endocrinol. Metab., 28: 693 (1968).

30. ICN Pharmaceuticals, Inc., Cleveland, Ohio.
31. Kindly provided by Abbott Laboratories, North Chicago, III.

32. This work was supported by Grant no. AM-05638-14 from the National Institute of Arthritis, Metabolic and Digestive Diseases of the National Institutes of Health and by the Pacific Northwest Research Foundation.

33. Requests for reprints should be addressed to: J. L. Bakke, M.D., Pacific Northwest Research Foundation, 1102 Columbia St., Seattle, Wash. 98104 (USA).

34. Accepted for publication May 19, 1975
Adrenergic blockade diabetes

glucagon growth hormone $\alpha$ - and $\beta$-receptors sympathetic activity

\title{
Effect of Adrenergic Blockade on Glucagon and Growth Hormone Secretion in Normal and Diabetic Children
}

\author{
MARK A. SPERLING(39) AND SANDRA VOINA \\ Department of Pediatrics, UCLA-Harbor General Hospital, Torrance, California, USA
}

\section{Extract}

Studies were conducted in four normal and six diabetic children to assess the role of adrenergic blockade on basal and arginine-stimulated growth hormone and glucagon secretion. Each subject had, on three separate occasions, infusion of arginine alone or in conjunction with $\alpha$ (phentolamine) or $\beta$ (propranolol) adrenergic blockade. Clinically, there was evidence of adequate blockade by each agent. Basal hormone growth levels were not significantly different in the two groups $(1.3 \pm 0.2$ to $2.1 \pm 1.0 \mathrm{ng} / \mathrm{ml}$ in normal subjects; $3.0 \pm 1.1$ to $6.0 \pm 3.1 \mathrm{ng} / \mathrm{ml}$ in diabetics (mean \pm 1 SEM)) but the peak growth hormone after arginine was significantly greater in the diabetic children than control subjects $\mathbf{3 4 . 3} \pm$ 7.2 versus $12.3 \pm 3.1$ ); in both groups $\alpha$-blockade suppressed the growth hormone response, whereas $\beta$-blockade had no significant effect. Basal glucagon concentrations were similar in both groups $(147 \pm 31$ to $214 \pm 21 \mathrm{pg} / \mathrm{ml}$ in normal subjects; $100 \pm 20$ to $124 \pm 17 \mathrm{pg} / \mathrm{ml}$ in diabetics on three different occasions) despite the coexistent hyperglycemia of the diabetics. Neither basal nor maximally stimulated glucagon secretion was significantly affected by $\alpha$ or $\beta$ blockade in the juvenile diabetic or control children. The results suggest that sympathetic overactivity via $\alpha$ receptors may contribute to the hypersecretion of growth hormone in juvenile diabetes and that the $\alpha$ or $\beta$ adrenergic receptor alone does not appear to modulate basal or arginine stimulated glucagon secretion.

\section{Speculation}

Sympathetic overactivity, documented in poorly controlled juvenile diabetic subjects may, via $\alpha$ receptors, be one of the mechanisms responsible for growth hormone hypersecretion in these subjects. Although the evidence suggesting a role for adrenergic stimuli in modulating glucagon secretion is compelling, the relative hypersecretion of glucagon in juvenile diabetics in response to arginine does not seem to be predominately influenced by either $\alpha$ or $\beta$ adrenergic receptors alone.

It has been firmly established that the adrenergic nervous system, through the release of catecholamines, is capable of modulating insulin and growth hormone secretion $(2,17,22,26$, $28,29,36)$. Recent data also implicate a role for adrenergic agonists in stimulating glucagon secretion (18). Anatomic and histologic studies demonstrate sympathetic nerve endings directly on the pancreatic islet $(9,18)$, and stimulation of the splanchnic sympathetic nerve in dogs (25), cats (8), and calves (4), causes a rise in glucagon secretion. In man, a variety of stressful situations $(3,10,30)$ as well as direct infusion of epinephrine $(12)$ result in a rise in plasma glucagon concentration. However, unlike insulin and growth hormone, where there is uniform agreement that the adrenergic effects are mediated via activation of adrenergic receptors which are inhibitory or stimulatory, the precise role of these receptors in modulating glucagon secretion remains uncertain. Activation of both $\alpha$ or $\beta$ adrenergic receptors has been reported to either stimulate or inhibit glucagon secretion $(7,11,13$, $14,16,18-20,23,36)$, and contradictory results have been reported within the same species, despite similarities in experimental design $(11,13,16,23)$.

To date few studies have focused on factors affecting glucagon secretion in normal and diabetic children. The present investigation in children was therefore undertaken in order to ascertain the effects of $\alpha$ or $\beta$ adrenergic blockade on basal and argininestimulated glucagon as well as growth hormone secretion. Because patients with juvenile diabetes have been reported to have inappropriately elevated glucagon and growth hormone concentrations in the basal and stimulated state $(32,34)$, it was anticipated that an effect of $\alpha$ or $\beta$ adrenergic blockage might be more apparent in this group.

\section{METHODS}

\section{SUBJECTS AND PROCEDURES}

Six juvenile diabetics, aged 11-16 years, and four normal children, 13-16 years, were each studied on three separate occasions with an intravenous arginine infusion, given either alone or in conjunction with $\alpha$ (phentolamine) or $\beta$ (propranolol) adrenergic blockade. At least 3 days elapsed between each study. 
In accordance with the Declaration of Helsinki informed written consent was obtained from parents, and all studies were approved by the institutional Human Use Committee. All patients were admitted between 8 and 9 AM to the Clinical Study Center after an overnight fast and remained recumbent throughout the study. An intravenous scalp needle was inserted into a vein in each antecubital fossa and maintained patent with a slow drip of $0.85 \%$ saline. For the diabetics, the usual morning dose of insulin was omitted and given at the conclusion of the test together with lunch. After two baseline blood samples $30 \mathrm{~min}$ apart were drawn, each subject received arginine monohydrochloride $0.5 \mathrm{~g} / \mathrm{kg}$ (maximum $25 \mathrm{~g}$ ) as a $5 \%$ solution in 0.85 saline over $30 \mathrm{~min}$. Blood samples were collected at 15 -min intervals for the first hour and $30-\mathrm{min}$ intervals for a second hour. A similar procedure was followed during the $\alpha$ or $\beta$ blockade, when the patients were closely monitored by attaching them to a recording and constant display oscilloscope for standard limb electrocardiography, by close supervision, and by measurement of puise and blood pressure.

The propranolol was given intravenously as a loading dose of 3 $\mathrm{mg}$ for those less than $50 \mathrm{~kg}$ and $5 \mathrm{mg}$ for those more than $50 \mathrm{~kg}$ in weight, over 5 min commencing $15 \mathrm{~min}$ before arginine infusion, and continued for $1 \mathrm{hr}$ at a dose of $0.08 \mathrm{mg} / \mathrm{min}$ by means of a Harvard constant infusion pump. An identical schedule was used for phentolamine given as a loading dose of $4 \mathrm{mg}$ and followed by $0.4 \mathrm{mg} / \mathrm{min}$ for a further hour. Thus, in the studies ascertaining the role of adrenergic blockade, the loading dose and continuous infusion had been ongoing for $15 \mathrm{~min}$ before 0 time, i.e., before the arginine infusion commenced, and extended for $15 \mathrm{~min}$ after arginine infusion had been completed.

\section{ANALYTICAL TECHNIQUES}

Each blood sample of $4 \mathrm{ml}$ was placed into chilled tubes containing EDTA and aprotinin (Trasylol), 2,000 $\mathrm{U}$ in $0.2 \mathrm{ml}$, promptly spun in a refrigerated centrifuge, and the plasma was separated and stored frozen at $-20^{\circ}$ until assayed. Each sample was analyzed for glucose by a glucose oxidase technique (24), growth hormone in duplicate, by radioimmunoassay described previously (27), and glucagon in duplicate by radioimmunoassay using the highly specific pancreatic glucagon antiserum G1-5, a technique from our laboratory described previously (31). All the radioimmunoassay procedures for each hormone were determined in a single assay run to obviate interassay variability.

Statistical analysis employed Student's $T$-test, and, where appropriate, the paired $T$-test.

\section{RESULTS}

Table 1 lists the details of the patients studied. There were no significant differences between the groups apart from fasting plasma glucose which was significantly elevated in the diabetic group. As a group, the diabetics could not be considered as being under good control; only one had fasting plasma glucose within the normal range. Although the mean of all three fasting plasma glucose determinations is shown, this is a true reflection of the values on all occasions.

During $\beta$ adrenergic blockade there was some slowing of the pulse in all patients but none was symptomatic. During $\alpha$ adrenergic blockade with phentolamine patients remained asymptomatic while recumbent, but all complained of nausea and dizziness upon standing up. These patients were found to have a difference of up to $30 \mathrm{~mm} \mathrm{Hg}$ systolic blood pressure on assuming the erect posture; symptoms abated upon reclining, and subsequently the constant infusion dose was reduced by $4 \mathrm{mg}$ (from 24 to $20 \mathrm{mg}$ ). Thus, clinically at least, there was evidence of effective adrenergic blockade. Apart from these side effects there were no major symptoms or sequelae in any of the paitents or subjects, and all returned to their usual state of health upon completion of each test.

Growth hormone responses are depicted in Figures 1 and 2 (Table 2). In the normal children a significant increment occurred at 30 and 45 min during the arginine alone or with $\beta$ blockade $(P<$ 0.05 ) but during $\alpha$ blockade the increment was no longer significant despite a mean peak value similar to that seen during arginine alone. A more striking effect of $\alpha$ adrenergic blockade was apparent in the diabetic group where the hyper-responsiveness of growth hormone release to arginine was suppressed, and no significant increment above basal was observed. The difference in response between arginine with or without $\alpha$ blockade was significantly different at $15(P<0.05)$ and $30(P<0.01) \mathrm{min} . \beta$ blockade tended to elevate mean basal growth hormone concentrations but because of marked individual variation and the large SEM there was no significant change.

Glucagon responses are depicted in Figures 3 and 4 . The basal value in all three tests ranged from $147 \pm 31 \mathrm{pg} / \mathrm{ml}$ to $214 \pm 21$ $\mathrm{pg} / \mathrm{ml}$ in normal children, and $100 \pm 20$ to $124 \pm 17 \mathrm{pg} / \mathrm{ml}$ in the diabetics. The difference in basal values between the normal and diabetic children was significant $(P<0.05)$ only during the propranolol study, but not during any other time.

Neither the basal nor arginine stimulated glucagon concentrations were significantly affected by $\alpha$ or $\beta$ blockade in normal or diabetic subjects (Fig. 3). Despite the minor differences in basal values, the maximal increment in glucagon concentrations after

Table 1. Clinical details of patients studied

\begin{tabular}{|c|c|c|c|c|c|c|c|c|}
\hline \multirow[b]{2}{*}{ Patient } & \multirow[b]{2}{*}{ Sex } & \multirow[b]{2}{*}{ Age, yr } & \multirow[b]{2}{*}{ Weight, kg } & \multicolumn{2}{|c|}{ Propranolol } & \multicolumn{2}{|c|}{ Phentolamine } & \multirow[b]{2}{*}{$\begin{array}{l}\text { Fasting } 1 \\
\text { blood } \\
\text { glucose } \\
\mathrm{mg} / 100 \mathrm{ml}\end{array}$} \\
\hline & & & & $\begin{array}{l}\text { Loading } \\
\text { dose, mg }\end{array}$ & $\begin{array}{l}\text { Constant } \\
\text { infusion } \\
\text { dose, mg }\end{array}$ & $\begin{array}{l}\text { Loading } \\
\text { dose, mg }\end{array}$ & $\begin{array}{l}\text { Constant } \\
\text { infusion } \\
\text { dose, mg }\end{array}$ & \\
\hline \multicolumn{9}{|l|}{ Diabetic } \\
\hline$C G$ & $\mathrm{M}$ & 16 & 69 & 5 & 4.8 & 4 & 24 & 263 \\
\hline$A S$ & $\mathrm{M}$ & 16 & 67 & 5 & 4.8 & 4 & 24 & 276 \\
\hline$S B$ & $M$ & 14 & 63 & 5 & 4.8 & 4 & 20 & 187 \\
\hline$R H$ & $\mathrm{~F}$ & 13 & 52 & 5 & 4.8 & 4 & 24 & 73 \\
\hline$J J$ & $\mathrm{~F}$ & 12 & 39 & 3 & 4.8 & 4 & 24 & 155 \\
\hline$B G$ & $\mathrm{M}$ & 11 & 41 & 3 & 4.8 & 4 & 24 & 295 \\
\hline \multicolumn{9}{|l|}{ Normal } \\
\hline$M K$ & $\mathrm{M}$ & 16 & 72 & 3 & 4.8 & 4 & 20 & 77 \\
\hline$D H$ & $\mathrm{M}$ & 15 & 51 & 5 & 4.8 & 4 & 20 & 87 \\
\hline$S K$ & $\mathrm{M}$ & 13 & 57 & 5 & 4.8 & 4 & 20 & 77 \\
\hline$K G$ & $M$ & 13 & 48 & 3 & 4.8 & 4 & 24 & 83 \\
\hline
\end{tabular}

${ }^{1}$ Mean of all three determinations in the fasting state. 
arginine stimulation was not different in normal or diabetic children, nor was it affected by $\alpha$ or $\beta$ adrenergic blockade (Fig. 4).

\section{DISCUSSION}

The role of the $\alpha$ adrenergic receptor in mediating growth hormone release is well established $(2,17)$ and hyper responsiveness of growth hormone release to a variety of stimuli has been reported previously in insulin-dependent diabetics (32). The exaggerated response is restored toward normal upon instituting careful control of the diabetic state (15). Since fasting blood glucose was significantly elevated in our group of diabetic children, they could not be considered under good control, and therefore, the hyper responsiveness of growth hormone release to arginine was expected. The abolition of this response by $\alpha$ blockade with phentolamine indicates that in addition to symptoms and signs of $\alpha$

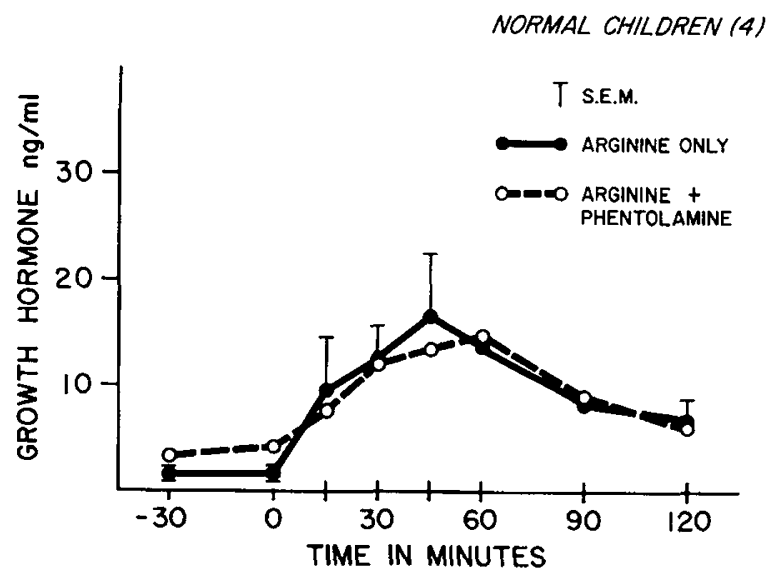

Fig. 1. Arginine-induced growth hormone secretion in normal children. During phentolamine blockade, although mean growth hormone values are similar to values with arginine alone, the rise is not significant because of large variation. Peak values during arginine infusion alone are significantly different from basal $(P<0.05)$. blockade, the dose employed was adequate to interfere with growth hormone release. Thus, it could be speculated that one of the mechanisms involved in the hyperresponsiveness of growth hormone release observed among poorly controlled diabetics is dependent on overactivity of the adrenergic nervous system affecting the $\alpha$ receptor. Support for this concept comes from studies showing that plasma and urinary catecholamines are elevated in juvenile diabetics under poor control $(1,5,6)$ and that this can be reversed with adequate insulin therapy (6). A lack of effect from the $\beta$ blockade in further augmenting growth hormone release in the diabetics might be explained on the basis of already existing maximal stimulation of the $\alpha$ receptor via endogenous catecholamines, an assumption which requires further documentation. Alternatively, previous studies indicate that $\beta$ blockade alone does not elevate growth hormone consistently (26).

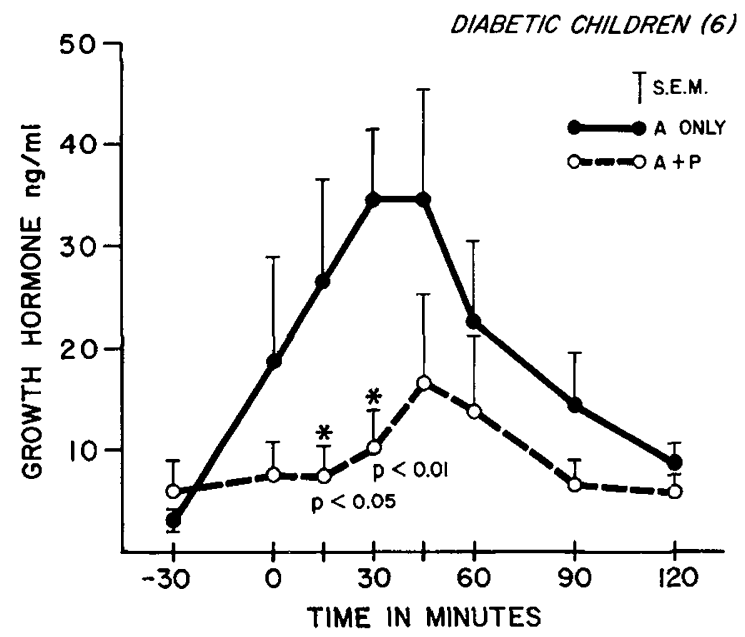

Fig. 2. Phentolamine inhibits growth hormone secretion after arginine administration in diabetic children. The differences between arginine only $(A O N L Y)$ and arginine with phentolamine $(A+P)$ are significantly different at 15 and $30 \mathrm{~min}$ as indicated.

at 15 and $30 \mathrm{~min}$ as indicated.

Table 2. Adrenergic modulation of arginine-induced growth hormone secretion ${ }^{1}$

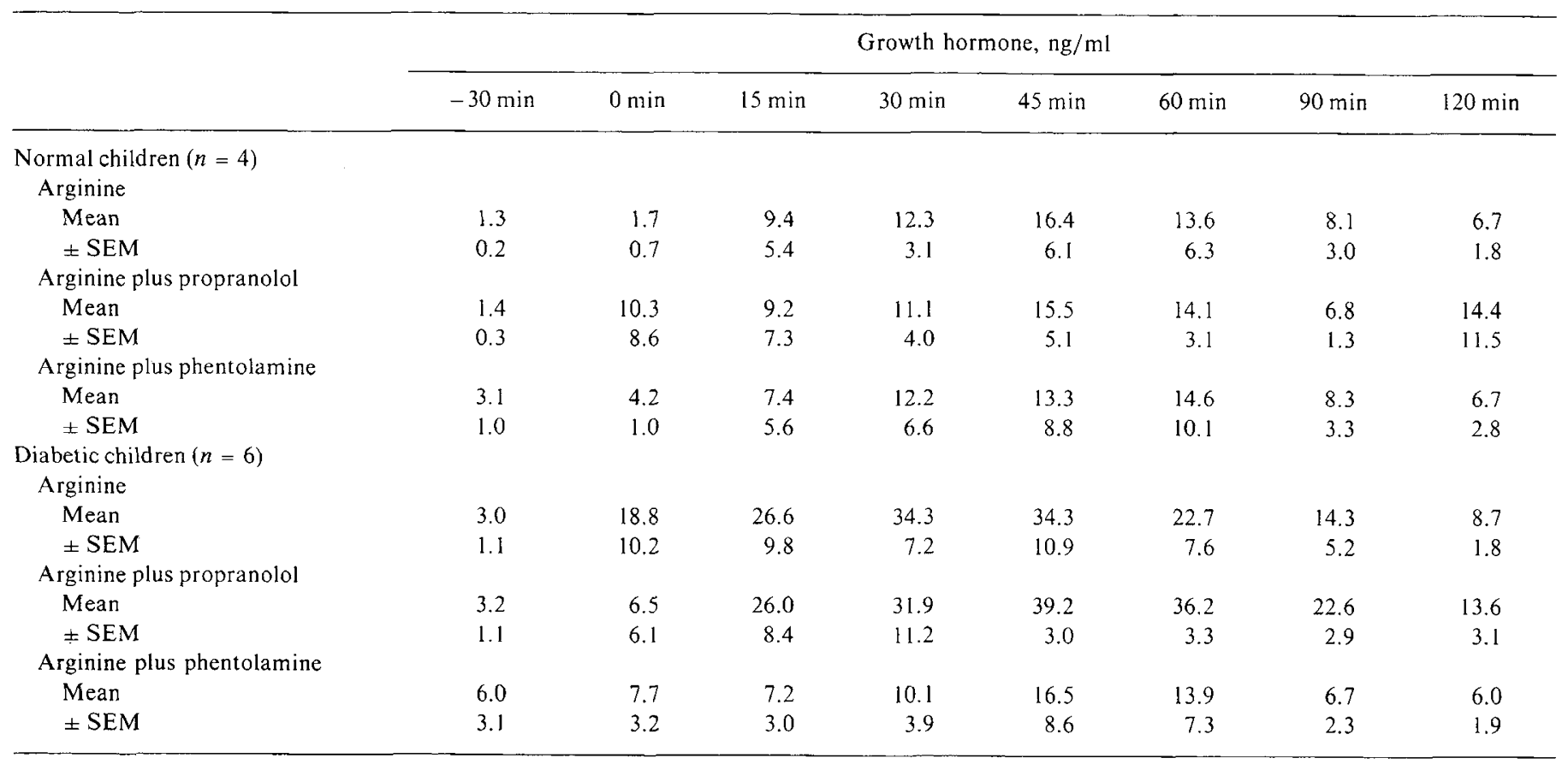

${ }^{1}$ A loading dose plus constant infusion of the blocking agent was given commencing 15 min before 0 time and extending to 15 min after terminating arginine. Arginine was infused over $30 \mathrm{~min}$ commencing at 0 time. 


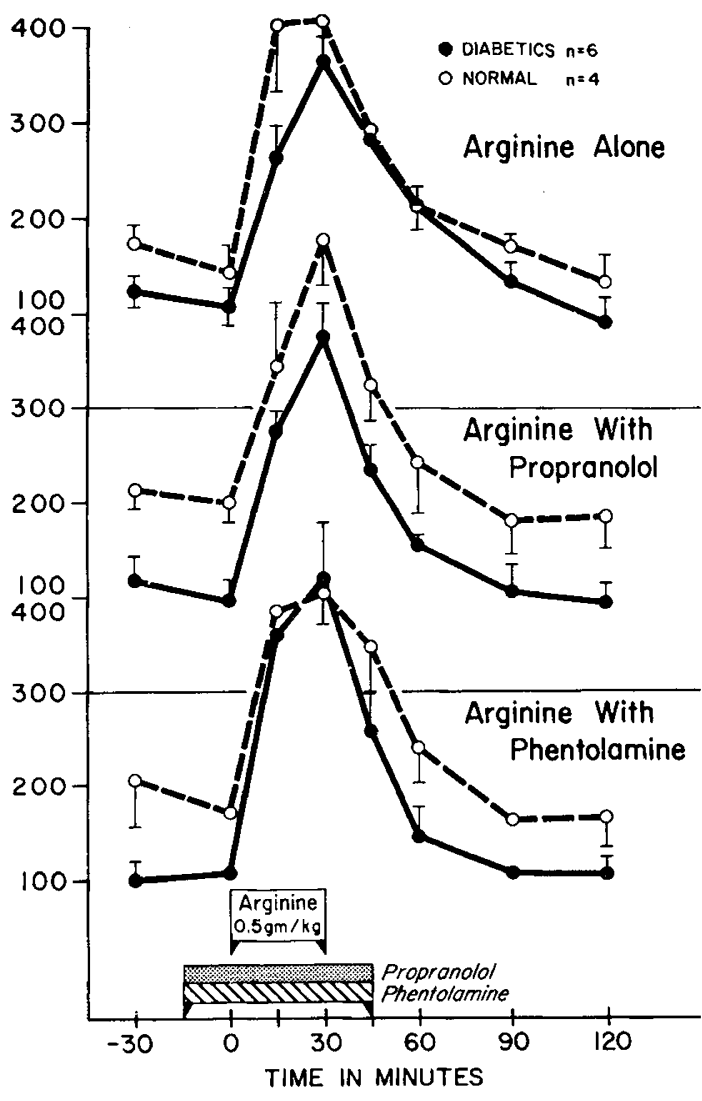

Fig. 3. Effect of adrenergic blockade on arginine-induced glucagon secretion (picograms per milliliter) in normal and diabetic children. The blocking agent was infused for $15 \mathrm{~min}$ before and 15 after arginine infusion. No significant differences are present. Vertical lines indicate I SEM.

As described previously by Unger et al. (34) for adults, basal plasma glucagon concentrations, as well as the response to arginine, were similar in the normal and diabetic children, despite the higher glucose values of the latter. In normal adults, elevating blood glucose lowers basal glucagon and blunts the response to arginine (33). Similarly, we have shown recently that in normal children (31), or in children with carbohydrate intolerance associated with cystic fibrosis (21), elevation of blood glucose suppresses plasma glucagon concentrations. Thus, the basal glucagon values and the response to arginine of the diabetic children, in the face of coexisting hyperglycemia, is an inappropriate response of the pancreatic $\alpha$ cell and confirms previous findings. In contrast to the demonstration of a clear-cut effect of $\alpha$ adrenergic blockade on growth hormone, neither $\alpha$ nor $\beta$ blockade had any appreciable effect on the glucagon response. The evidence supporting an influence of the adrenergic nervous system on glucagon secretion is very compelling, as recently reviewed (36), but the precise role of the adrenergic receptors in mediating this response is disputed. Thus, in man, Gerich et al. (13) have suggested that $\beta$ adrenergic stimulation augments basal glucagon secretion, and that $\alpha$ adrenergic stimulation diminishes glucagon secretion, although no change resulted from $\beta$ blockade alone. These same authors have claimed elsewhere (11) that $\alpha$ but not $\beta$ adrenergic blockade inhibits the stimulation of glucagon by catecholamines. More recently, Walter et al. (35) could not demonstrate any effect of sustained $\alpha$ or $\beta$ adrenergic blockade in modifying the elevation of glucagon induced by prolonged fasting or insulin-induced hypoglycemia, situations in which a rise in endogenous catecholamines is to be expected. The present investigation in children also failed to demonstrate any appreciable effect of adrenergic blockade on basal and arginine stimulated glucagon secretion.

In those studies in which an effect of adrenergic blockade has been reported, it has been apparent within 10-20 min. Since in our

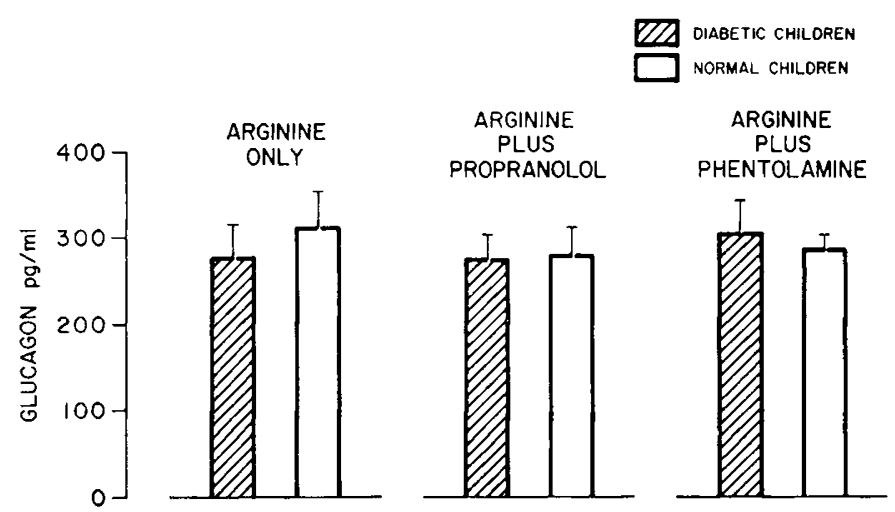

Fig. 4. Lack of significant difference in maximal glucagon secretion between normal and diabetic children after arginine stimulation alone, or in the presence of $\beta$ (propranolol) or $\alpha$ (phentolamine) adrenergic blockade. The vertical lines indicate I SEM.

studies the blocking agent was infused for at least 15 min before commencing arginine, and since an effect on growth hormone release by arginine was certainly apparent, we cannot invoke inadequate dose or duration of infusion to explain our results. Moreover, most of the conflicting reports have utilized the same antiserum to measure glucagon (30K), so that the use of our own antiserum in these studies, although a possible contributing factor, cannot be the sole reason for our failure to demonstrate an effect of adrenergic blockade. In view of the reports of elevations of plasma glucagon by direct neural stimulation, by states of stress, and by epinephrine and norepinephrine (36), situations in which both $\alpha$ and $\beta$ adrenergic receptors are stimulated, it is conceivable that both are involved in mediating glucagon secretion, without either one predominating. This would be compatible with the divergent reports, and with our findings. Finally, the stimulation of giucagon secretion by arginine does not appear to be mediated via $\alpha$ or $\beta$ adrenergic receptors.

\section{SUMMARY}

The effects of adrenergic blockade on glucagon and growth hormone secretion were investigated in normal and diabetic children. Absolute hypersecretion of growth hormone and relative hypersecretion of glucagon was demonstrated in the diabetics. Adrenergic block ade significantly inhibited growth hormone secretion in both groups, whereas $\beta$ adrenergic blockade had no effect. Neither $\alpha$ nor $\beta$ adrenergic blockade influenced basal or argininestimulated glucagon secretion in the diabetic or normal subjects. Thus, $\alpha$ adrenergic receptors may be involved in the hypersecretion of growth hormone among diabetic subjects, but a predominant role for either adrenergic receptor alone cannot be implicated in the relative hypersecretion of glucagon after arginine infusion in diabetic children.

\section{REFERENCES AND NOTES}

1. Assan, R., Dauchy, F., and Boyet, P.: Elevated vanyl-mandelic acid excretion in severe diabetic ketoacidosis. Pathol. Biol., 21: 27 (1973).

2. Blackard, W. G., and Heidingsfelder, S. A.: Adrenergic receptor control mechanism for growth hormone secretion. J. Clin. Invest., 47: 1407 (1968).

3. Bloom, S. R.: Glucagon, a stress hormone. Postgrad. Med. J., 49: 607 (1973).

4. Bloom, S. R., Edwards, A. V., and Vaughan, N. J. A.: The role of sympathetic innervation in the control of plasma glucagon concentration in the calf. $J$. Physiol., 233: 457 (1973).

5. Christensen, N. J.: Abnormally high plasma catecholamines at rest and during exercise in ketotic juvenile diabetics. Scand. J. Clin. Lab. Invest., 26: 343 (1970).

6. Christensen, N. J.: Plasma norepinephrine and epinephrine in untreated diabetics during fasting and after insulin administration. Diabetes, 23: I (1974).

7. Eaton, R., Conway, M., and Buckman, M.: Role of alpha-adrenergic blockade on alanine-induced hyperglucagonemia. Metabolism, 21: 371 (1972).

8. Esterhuizen, A. C., and Howell, S. L.: Ultrastructure of the A-cells of cat islets of Langerhans following sympathetic stimulation of glucagon secretion. J. Cell Biol., 46: 593 (1970). 
9. Esterhuizen. A. C.. Spriggs, T. L., and Tever, J. D.: Nature of islet-cell innervation in the cat pancreas. Diabetes, 17: 33, (1968).

10. Felig. P.. Wahren, J.. Hendler, R., and Ahlborg, G.: Plasma glucagon levels in exercising man. N. Engl. J. Med., 287: 184 (1972).

11. Gerich, J. E., Karam, J. H., and Forsham, P. H.: Reciprocal adrenergic control of pancreatic alpha and beta-cell function in man. Diabetes, 21: 332 (1972).

12. Gerich. J. E.. Karam. J. H., and Forsham, P. H.: Stimulation of glucagon secretion by epinephrine in man. J. Clin. Endocrinol. Metab.. 37: 479 (1973).

13. Gerich, J. E., Langlois, M., Noacco, C., Schneider, V., and Forsham, P. H.: Adrenergic modulation of pancreatic glucagon secretion in man. J. Clin. Invest., 53: 1441 (1973)

14. Gerich, J. E., Schneider, V. S., Dippe, S., Gustafson, G. M., Karmam, J. H., and Forsham, P. H.: Adrenergic modification of glucagon and insulin responses to arginine in man [Abstract]. Clin. Res., 21: 273 (1973).

15. Hansen. H. P., and Mogensen, C. E.: Growth hormone secretion and kidney function during normalization of the metabolic state in newly diagnosed juvenile diabetics. Hormone Metab. Res., 4: 11 (1972).

16. Harvey, W. D., Faloona, G. R., and Unger, R. H.: The effect of adrenergic blockade on exercise-induced hyperglucagonemia. Endocrinology, 94: 1254 (1974).

17. Imura, H., Kata, Y., Ikeda, M., Morimoto, M., and Yawata, M.: Effect of adrenergic-blocking or stimulating agents on plasma growth hormone, immuno-reactive insulin, and blood free fatty acid levels in man. J. Clin. Invest., 50: 1069 (1971).

18. Iversen, J.: Adrenergic receptors and the secretion of glucagon and insulin from the isolated perfused canine pancreas. J. Clin. Invest., 52: 2102 (1973).

19. Lawrence, A. M., Hagen, T. C., and Kirsteins, L.: Glucagon and growth hormone in ketosis-prone diabetes mellitus. Clin Res., 21: 846 (1973).

20. Lindsay, C. A., and Faloona, G. R.: Adrenergic blockade in shock-induced hyperglucagonemia. Diabetes, 22: 301 (1973).

21. Lippe, B., Sperling, M. and Dooley, R.: Pancreatic alpha and beta cell function in children with cystic fibrosis [Abstract]. Pediat. Res., 8: 435 (1974).

22. Loubatieres, A., Mariani, M. N., Sorez, G., and Savi, L.: The action of beta adrenergic blocking and stimulating agents on insulin secretion: characterization of the type of beta receptor. Diabetologia, 7: 127 (1971).

23. Luyckx, A. S., and Lefebvre, P. H.: Mechanisms involved in the exercise-induced increase in glucagon secretion in rats. Diabetes, 23: 81 (1974).

24. Marks, V.: An improved glucose oxidase method for determining blood, CSF, and urine glucose levels: Clin. Chem. Acta, 4: 395 (1959).
25. Marliss, E. B., Girardier, L., Seydoux, J., Wollheim, C. B., Kanazawa, Y., Orci, L., Renold, A. E., and Porte, D.: Glucagon release induced by pancreatic nerve stimulation in the dog. J. Clin. Invest., 52: 1246 (1973).

26. Martin. J. B.: Neural regulation of growth hormone secretion. N. Engl. J. Med., 288- 1384 (1973).

27. Odell, W. D., Rayford, P. L., and Ross, G. T.: Simplified, partially automated method for radioimmunoassay of human thyroid stimulating. growth, luteinizing and follicle stimulating hormones. J. Lab. Clin. Med., 70: 973 (1967).

28. Porte, D., Jr.: A receptor mechanism for the inhibition of insulin release by epinephrine: J. Clin. Invest., 46: 86 (1967).

29. Porte, D., Jr., and Robertson, R. P.: Control of insulin secretion by catecholamines, stress, and the sympathetic nervous system. Fed. Proc 32: 1792 (1973).

30. Rocha, D. M., Santeusanio, F., Faloona, G. R., and Unger, R. H.: Abnormal pancreatic alpha-cell function in bacterial infections. N. Engl. J. Med., 288: $700(1973)$.

31. Sperling, M. A., DeLamater, P. V., Kazenelson, M., Fiser, R. H., Jr., and Fisher, D. A.: Development and application of a radioimmunoassay for plasma glucagon. Clin. Chem., 20: 566 (1974).

32. Sperling, M. A., Wollesen, F., and DeLamater, P. V.: Daily production and metabolic clearance of growth hormone in juvenile diabetes mellitus. Diabetologia, 9: 380 (1973).

33. Unger, R. H.: Alpha- and beta-cell interrelations in health and disease. Metabolism, 23: 581 (1974).

34. Unger, R. H., Aguilar-Parada, Muller, W. A., and Eisentraut, A. M.: Studies of pancreatic alpha cell function in normal and diabetic subjects. J. Clin. Invest., 49: 837 (1970).

35. Walter, R. M., Dudl, R. H., Palmer, J. P., and Ensinck, J.W.: The effect of adrenergic blockade on the glucagon responses to starvation and hypoglycemia in man. J. Clin. Invest., 54: 1214 (1974).

36. Woods, S. C., and Prote, D., Jr.: Neural control of the endocrine pancreas. Physiol. Rev. 54: 596 (1974).

37. Dr. M. A. Sperling is a recipient of a Research Career Development Award from the United States Public Health Service (1 KO4 HD0029).

38. This research was supported by United States Public Health Service Grants Nos. HD-07087 and RR-425.

39. Requests for reprints should be addressed to: M. A. Sperling, M.B., FRACP., Harbor General Hospital, B-5, 1000 W. Carson St., Torrance, Calif. 90509 (USA).

40. Accepted for publication May 19, 1975.
Brain

cortisol, hydrocortisone

developmental biochemistry fatty acid biosynthesis lung surfactant

\title{
The Influence of Cortisol on the Enzymes of Fatty Acid Synthesis in Developing Mammalian Lung and Brain
}

\author{
IAN GROSS, ${ }^{31}$ SEAMUS A. ROONEY, AND JOSEPH B. WARSHAW \\ Division of Perinatal Medicine, Departments of Pediatrics and Obstetrics and Gynecology, and Lung Research \\ Center, Yale University School of Medicine, New Haven, Connecticut, USA
}

\section{Extract}

Administration of cortisol to fetal rabbits resulted in a $42 \%$ inhibition of pulmonary de novo fatty acid synthesis from acetyl coenzyme A $(\mathrm{CoA})(P=<0.025)$. This was associated with inhibition of acetyl-Co A carboxylase (EC. 6.4.1.2) activity $(P=$ $<0.01)$ and a tendency towards decreased activity of fatty acid synthetase. There was no effect on pulmonary microsomal fatty acid elongation activity. Light and electron microscopic examination of the apex of the right lung of control and cortisol-treated animals revealed changes consistent with accelerated lung maturation in the treated animals.
The in vitro activities of acetyl-Co A carboxylase and fatty acid synthetase were similar in rabbit lung and thus acetyl-Co $\mathrm{A}$ carboxylase activity does not appear to be rate limiting for de novo fatty acid synthesis in lung.

No significant change in the activity of enzymes associated with de novo fatty acid synthesis or microsomal fatty acid elongation was found in fetal brain after cortisol exposure. However, in a parallel study on fatty acid synthesis in fetal liver, cortisol administration resulted in a $\mathbf{3 0} \%$ increase in fatty acid synthetase activity $(P=<\mathbf{0 . 0 2 5})$.

The finding of cortisol-induced inhibition of de novo fatty 